\title{
Musik Tradisional Jawa Janengan yang Terlupakan (A Forgotten Javanese Traditional Music Janengan)
}

\author{
Mukarom \\ Program Studi Pendidikan Bahasa Inggris IKIP Budi Utomo Malang \\ Jalan Citandui 46 \\ rommukarom@gmail.com. \\ Rochsun \\ Program Studi Pendidikan Matematika IKIP Budi Utomo Malang \\ Jalan Citandui 46 \\ rochsun-mkes@yahoo.com.
}

\begin{abstract}
Villagers of Waringinsari, Sukoharjo sub-district, Pringsewu district, Lampung province grows and develops from voluntary migrants from Java. They are a group of marginalized people economically, politically, socially and culturally, so they expected so much when migrating to get a better life for his family. Residents who occupy Waringinsari village as the voluntary migrants are from different regions. They were farmers who had come from the fields of Java (Central, East and West) to gain ground as a new livelihood. The question is why with all kinds of differences in the Javanese sub-culture they could then dissolve together, and then they feel just as Javanese (in the sense of not distinguishing which Javanese origin). The research was carried out to get an answer whether janengan contributing music as media of entertainment, communication and propagation for villagers of voluntary migrants in the Waringinsari village, Suhoharjo Sub-district, Pringsewu district, Lampung province. This research is qualitative. The data obtained show that janengan music does really as alternative music that is able to show the identity of the people of Java. Janengan identifies the Javanese sub-culture from Kebumen which later became the common property of the voluntary migrants. They feel a sense of musical art is proven fact that until now is still a viable alternative enter tainment. Janengan also contribute to the cohesiveness, and was able to eliminate the bulkhead sub-culture of their respective regions of origin. Music janengan is able to be an alternative as a cheap entertainment media, as a means of gathering spontaneous migrants thus establish communication in the period since the beginning of the village to the present, the past 60 years. In addition, the content of the janengan music lyric also provide a moral message that as human beings they are not arrogant, and able to follow prophets. Janengan is able to instill the values to the younger generation so that they can become good human in morality as told in the poem of janengan.
\end{abstract}

Keyzords: traditional music, janengan

Gagalnya penampilan Lady Gaga yang akan melakukan pentas di Jakarta pada awal Juni 2012, tampaknya membuka mata kita betapa dunia seni, dalam hal ini seni musik, mampu menghipnotis dan mencuri perhatian hampir semua orang. Dunia musik mampu melibatkan hampir semua elemen masyarakat dan bahkan pemerintah kerepotan dibuatnya.

Hasil penelitian Andrew N. Weintraub yang dibukukan dengan judul Dangdut (2012) menunjukkan betapa musik dangdut mampu melibatkanemosidanpikiranparapenggemarnya pada semua umur dan golongan masyarakat. Pada pentas musik dangdut di tempat terbuka (di lapangan, tempat kampanye parpol untuk calon pejabat pusat-daerah), para remaja, mudamudi, orang tua, ibu rumah tangga, dan bahkan anak-anak berduyun-duyun mendatangi tidak hanya sekadar mendengarkan suara penyanyi, tetapi juga erotisme yang ditujukkan para biduan. Sementara pada ruang-ruang tertutup, pertunjukan dangdut juga dengan mudah didapatkan pada gedung-gedung pertujukan, rumah makan, kafe, tempat karaoke, dll.

Sementara itu ruang tamu, ruang baca, ruang tidur dan hampir semua sudut rumah bisa di sisipi musik melalui berbeda media, semisal: $\mathrm{TV}$, radio, komputer, $\mathrm{MP3}, \mathrm{MP} 4$, tablet, dan lain- 
lain. Perkembangan teknologi informasi dan komunikasi memungkinkan penyebaran musik dapat mencapai wilayah yang sangat luas dalam waktu singkat. Setiap orang dapat menikmati musik di semua tempat dengan berbagai macam media sesuai yang dipilihannya. Agus (2010:155) menyatakan bahwa seni adalah aspek budaya yang cukup penting. Tidak ada masyarakat walaupun primitif sekalipun yang hidup tanpa seni. Seni mengacu kepada perasaan yang cenderung senang kepada keindahan. Karya seni adalah karya yang menampilkan keindahan. Menurut Agus manusia dalam pandangan Islam memiliki dimensi fisik, akal, rasa, dan hati (Q.S. 32:7-9; 2:9, 12, 44, 72,76, dan lain-lain).

Terkait dengan religi, seni menyandang fungsi ritual telah terbukti berabad-abad lamanya dan kehadirannya cukup menonjol hampir di semua agama atau kepercayaan di dunia, terutama dalam pola peribadatan. Hal ini dibuktikan dengan berbagai temuan di belahan dunia misalnya di Perancis Selatan dan Spanyol (diperkirakan 60.000-10.000 tahun yang lampau) berupa teraan goresan-goresan, bekas tapak tangan, lukisan, dan patung. Dalam penelitiannya, Hadi menunjukkan bahwa dunia agama sangat erat dengan musik karena pada setiap ritul keagamaan para umat (Katolik) akan selalu disertai irama musik (Hadi, 2006:XV).

Tidak semua bentuk seni dan aneka ragam ekspresi estetik berkembang sama dalam setiap kebudayaan. Kesenian dan corak bentuk ungkapan cenderung berbeda pada setiap kebudayaan, bahkan pada lapisan tertentu. Perbedaan dalam bentuk dan corak ungkapan kesenian tersebut tidak semata-mata berkaitan dengan pemenuhan kebutuhan estetik saja, namun juga terkait secara integral dengan pemenuhan kebutuhan hidup lainnya, baik kebutuhan primer maupun sekunder. Ada pertalian erat antara adat-istiadat, tuntutan ekonomi, upacara religi, dan ekspresi estetik. Perbedaan tidak saja bisa muncul pada hubungan yang bersifat horizontal, tetapi juga vertikal berkaitan dengan lapisan-lapisan sosial tertentu, sehingga lahir aneka ragam seni seperti seni pop, seni petani, seni rakyat, seni borjuis, dan sebagainya (Rohidi, 2000:18).

Manusia dan budaya itu sangat lekat, bahkan seandainya mereka pindah tempat tinggal sekalipun. Sebagai contoh, budaya Jawa masih dipelihara oleh masyarakat transmigran, masyarakat Jawa yang telah berpindah ke provinsi Lampung puluhan tahun silam. Dalam proses perubahan sosial yang terus terjadi, budaya asli dari masyarakat Jawa tetap terpelihara. Pada bidang seni, misalnya, ada beberapa jenis kesenian tradisional yang sempat tumbuh dan melekat pada masyarakat Jawa di Lampung, semisal: kuda lumping (jaranan), ketoprak, wayang kulit, janger, dan lain-lain. Pada setiap pertunjukan seni tersebut selalu muncul aroma dan warna ke-Jawa-an yang kental: ritual, sesajen, penganan, sampai pada semua aktivitas penyertanya. Koentjaraningrat (1990:190) menyatakan:

Walaupun nilai-nilai budaya berfungsi
sebagai pedoman hidup manusia
dalam masyarakat, tetapi sebagai
konsep, nilai budaya bersifat sangat
umum, mempunyai ruang lingkup
yang sangat luas, dan biasanya sangat
sulit diterangkan secara rasional dan
nyata. Namun justru karena sifatnya
yang umum, luas dan tak konkrit itu,
maka nilai-nilai budaya dalam suatu
kebudayaan berada dalam daerah
emosional dari alam jiwa para individu
yang menjadi warga dari kebebudayaan
yang bersangkutan.

Kesenian dalam wujudnya dapat dibagi menjadi tiga kelompol besar, yaitu ekspresi seni yang bersifat visual (seni netra), auditori (seni rungu), dan auditori-visual (seni netra-rungu). Ekspresi seni yang bersifat visual adalah semua bentuk seni hasil karya manusia yang dapat dinikmati melalui indra penglihatan, auditori adalah hasil karya seni yang dapat dinikmati manusia melalui kemampuan dengar, dan auditori-visual adalah kesenian yang dapat dicerap manusia melalui indra penglihatan dan pendenagran secara bersama-sama (Rohidi, 2000:38).

Sementara itu, Koentjaraningrat (1990:381) membagi dua kelompok kesenian yaitu: (1) seni rupa, kesenian yang dinikmati manusia dengan mata dan (2) seni suara, kesenian yang dinikmati oleh manusia melalui telinga. Koentjaraningrat menambahkan bahwa: (1) seni rupa terdiri atas: (a) seni patung, (b) seni relief, (c) seni lukis/ gambar, dan (d) seni rias; sedangkan (2) seni suara mencakup: (a) seni vocal, (b) seni instrumenal, dan (c) seni sastera (prosa dan puisi)

Rohidi mencoba menggambarkan bagaima- 
na kebutuhan rasa seni (sebagai kebutuhan adaptif tetap ada pada masyarakat miskin. Berbeda dengan masyarakat berpunya yang kebutuhan dasar (sandang, pangan, papan) dan kebutuhan sekunder sudah tidak menjadi persoalan, sementara masyarakat miskin untuk mencukupi primer dan sekunder masih menjadi persoalan. Kebutuhan adaptif menurut Rohidi merupakan kebutuhan tahap ketiga, setelah kebutuhan primer dan sekunder. Rohidi menegaskan bahwa walaupun secara ekonomi masyarakat masuk kategori kekurangan, namun senantiasa bisa hadir dengan seni dengan berbagai bentuk ungkapan (syair).

Musik umumnya dianggap sebagai salah satu media hiburan paling universal karena dengan musik semua orang merasa senasib, merasa sepenanggungan, merasa satu kelompok, dan merasa terhibur bersama. Walaupun setiap orang bisa menyukai jenis musik yang berbeda, namun ada perasaan yang sama pada mereka, terhibur. Ada banyak jenis musik, seperti: rock, jazz, pop, country, keroncong, melayu, dangdut, dan lain-lain. Musik bisa dikelompokan menjadi dua macam, musik modern dan tradisional. Musik modern biasanya merujuk pada jenis pop, jazz, country, rock dan sejenisnya. Musik ini memiliki penggemar yang lebih masif dengan segmen umur yang lebih luas, apalagi penyebarannya didukung dengan berbagai macam perkembangan alat dan teknologi modern.

Walaupun secara ekonomi masyarakat transmigran swakarsa di kabupaten Pringsewu, Lampung masuk kategori kekurangan, namun senantiasa bisa hadir dengan seni dengan berbagai bentuk ungkapan (syair). Manusia tidak bisa lepas dari budaya tempat dimana mereka tinggal, karena ia tidak akan dapat keluar dari struktur sosial. Keterikatan manusia pada budaya tersebut bisa meliputi cara berpikir, cara berencana, cara bertindak; dan semua hasil karya nyata yang dianggap berguna dan benar akan dipatuhi seluruh anggota masyarakat (Pamungkas, 2009:2).

Tulisan ini menggali kontribusi musik janengan pada masyarakat transmigran swakarsa yang tidak tampak ada sekat dan perbedaan, guyub rukun bertetangga dan saling membantu pada hal berasal dari sub-kultur beda. Janengan, sebuah musik tradisional masyarakat migran, menarik untuk didiskusikan karena selama 60 tahun lebih proses perubahan sosial masyarakat transmigran swakarsa (sejak keberadaan masyarakat sampai kini), masih tetap eksis menjadi media hiburan bagi sekelompok masyarakat. Selama proses pembauran, banyak dari pelaku tidak mengetahui secara persis musik janengan itu berasal dari daerah (Jawa) mana. Mereka terlibat langsung pada kegiatan kesenian, namun tidak pernah mempertanyakan mengapa mereka ikut. Juga tidak pernah mempersoalkan dari mana musik itu berasal. Juga, sejauh pengamatan penulis, belum ada penelitian tentang musik janengan yang mempertanyakan sejauh mana kontribusi musik ini sebagai media komunikasi pada masyarakat transmigran swakarsa. Hasil pengamatan menunjukkan bahwa para komunitas musik janengan melakukan dengan senang hati karena mereka merasa saling bertetangga, bisa membaur dan merasa sesama orang Jawa. Tampaknya ada sebuah makna, simbol, dan perwujudan eksistensi masyarakat pada musik Janengan itu.

Sebenarnya ada beberapa jenis kesenian tradisional lain yang tetap melekat pada masyarakat Jawa di Lampung, semisal: Kuda Lumping (Jaranan), Ketoprak, Wayang Kulit, Janger, dan lain-lain. Namun demikian telah terjadi pergeseran tingkat kesenangan dan frekuensi pertunjukan berbagai jenis kesenian tersebut karena pengaruh media massa. Tidak demikian untuk musik janengan, para pelaku tetap konsisten bernusik sampai sekarang. Oleh sebab itu, fenomena ini sangat menarik untuk diteliti karena fenomena ini terjadi pada masyarakat yang mengalami perubahan pada semua aspek (sosial, budaya, ekonomi, dan bahkan politik).

Berdasarkan uraian di atas, maka tulisan ini akan menguraikan: (a) bagaimana musik janengan berperan sebagai media hiburan, (b) media komunikasi, dan (c) media dakwah bagi masyarakat transmigran swakarsa di desa Waringisari,Sukoharjo, Pringsewu. Waringinsari dipilih sebagai representsi tempat kajian karena desa bisa dianggap mewakili objek kajian dimana kesenian musik janengan masih biasa dinikmati. Musik janengan masih aktif digelar sampai saat ini untuk memenuhi kebutuhan seni bagi masyarakat transmigran.

\section{METODE}

Penelitian kualitatif ini melibatkan partisipasiaktif peneliti terhadap objek kajian. Wawancara 
dilakukan peneliti untuk mendapatkan data tentang berbagai hal terkait musik janengan. Teknik dokumentasi dilakukan terkait dengan demografi desa, potensi daerah, dan serta syair-syair musik janengan. Atas pertimbangan kesesuai dengan topik penelitian ini, maka peneliti menetapkan wilayah desa Warigninsari Kecamatan Sukoharjo Kabupaten Pringsewu Provinsi Lampung sebagai tempat penelitian. Desa ini dipilih karena bisa dianggap mewakili subjek kajian dimana musik jenengan sebagai media hiburan, komunikasi, dan dakwah masih bisa ditemukan.

Pertimbangan lain karena: (a) kecamatan Sukoharjo Kabupaten Pringsewu, khususnya desa Waringinsari dapat dipandang mampu merepresentasikan masyarakat transmigran swakarsa di provinsi Lampung, bahkan mungkin di Indonesia; (b) sampai saat ini di desa Waringinsari masih dapat ditemukan gelaran musik janengan. Dengan argumentasi tersebut di atas, maka menurut peneliti desa Waringinsari layak untuk dijadikan tempat dilakukan penelitian. Dalam rangka memperoteh data yang cukup maka peneliti menggunakan teknik pengumpulan data melalui dokumen, wawancara mendalam; dan observasi partisipatif. Selama melakukan observasi ini, peneliti melakukan pencatatan dan pendokumentasian (foto dan video) sedangkan saat melakukan wawancara mendalam kepada informan peneliti hampir selalu melakukan perekaman dengan alat perekam, dan sebagian data yang tidak melalui rekaman diusahakan segera melakukan pencatatan.

Analisis data tentang monografi desa akan dianalisis dengan "analisis deskriptif kualitatif", yaitu mendeskripsikan profil desa. Untuk melacak latar belakang dan sejarah proses berdirinya desa transmigran swakarsa dilacak malalui informan yang mengalami kehidupan masa proses pembukaan daerah yang masih hidup, atau setidak-tidaknya mereka yang mengetahui proses berdirinya desa tersebut. Analisis dilakukan dengan cara yang sama untuk pelaku musik janengan tentang: (a) fungsi musik bagi komunitas; (b) fungsi musik dalam peranan sosial antara, (c) orientasi nilai-norma agama yang dianut komunitas pemusik, dan lain-lain.

\section{HASIL}

Alat musik jenengan terdiri dari beberapa jenis, yaitu: gong, kempul, kempyang, kendang, kecapi (kecrek), dan calung. Dilihat dari bahan baku yang digunakan sebagai, terlihat bahwa hampir semua alat musik dihasilkan secara tradisional yang dihasilkan secara turun-temurun. Kayu, bambu, dan kulit binatang sebagai bahan baku menunjukkan bahwa ketrampilan membuatnya dapat dihasilkan secara turun-temurun. Hanya kecapi alat yang tidak didapat diproduksi sendiri karena menggunakan bahan baku logam. Dilihat dari bahan yang digunakan, tampaknya alat inilah yang menjadi unsur bahwa musikjenengan sudah mendapatkan pengaruh luar. Alat ini mirip yang digunakan pada genjring (arab), khasidah, hadrah, atau pada musik dangdut.

Perubahan yang terjadi dan menarik diamati pada alat musik jenengan adalah calung. Alat berbahan dasar bambu ini awalnya tidak dikenal di musikjenengan, sampai akhirya muncul sekitar tahun 2000-an. Alat ini menggantikan fungsi ketipung. Ketipung adalah alat mirip dengan kendang tetapi berukuran kecil dengan panjang sekitar 25-30 cm, berbahan dasar kayu dan kulit binatang sebagaimana gendang. Awalnya ada dua ketipung, yang satu dipukul pada bagian sisi yang kecil sedang ketipung lain dipukul pada sisi permukaan yang lebih besar. Cara memukul ini untuk menghasilakan kombinasi suara yang lain dan enak dinikmati.

Kaliyo (75), salah satu tokoh jenengan, menjelaskan bahwa suatu ketika ketipung yang di miliki mengalami kerusakan. Pada saat dilakukan perbaikan mereka mengalami kesulitan. Bahkan perbaikan dengan cara memotong sebagian sisi ketipung tidak berhasil dengan baik, sampai kemudian muncul ide alternatif untuk mengganti dengan calung.

Musik jenengan dimainkan oleh enam orang. Sesekali dimainkan oleh tujuh orang. Mereka adalah penabuh kendang, gong, kempul, kempyang, kecapi dan calung. Penabuh bisa menjadi tujuh kalau calung dipukul oleh dua orang. Keterampilan memainkan alat musik masing-masing akan sangat menentukan keharmonisan suara yang dihasilkan, sehingga dibutuhkan sensitifitas masing-masing penabuh untuk memperhatikan ketukan kapan saat yang paling tepat memukul alatnya. Sedikit saja ada 
penabuh yang terlambat memukul maka akan terasa irama yang dihasilkan akan menjadi kurang enak. Kaliyo (75) menjelaskan bahwa untuk menjadi pemain yang baik dibutuhkan latihan yang cukup, selain talenta yang dimiliki. Mereka seolah sudah memiliki spesialisasi alat musik mana yang dimainkannya. Pemain yang terampil menabuh kendang tampaknya menjadi kunci permainan musik ini. Tidak banyak diantara pemain musik jenengan yang terampil memainkan kendang, apalagi dengan berbagai variasi irama. Sedang alat musik lain lebih mudah berpindah tangan dari pemain satu ke pemain lainnya.

Walaupun jumlah pemain janengan terdiri dari lima atau enam orang, namun demikian jumlah anggota kelompok berkisar 15-20 orang, bahkan saat-saat awal booming latihan bisa mencapai 30 orang. Satu kelompok musik jenengan akan memiliki dua-tiga dalang. Mereka adalah orang yang dianggap memiliki suara paling bagus diantara anggota yang lain. Namun demikian, anggota lain tetap diperlukan untuk menjadi suara makmum. Sesekali sambil bernyanyi, dalang juga sambil memainkan salah satu alat musik (kempul atau kempyang).

Sebelum pagelaran musik Janengan dimulai, biasa diawali dengan pembacaan surat al Fatihah yang ditujukan kepada nabi Muhammad, para sahabat, dan para tabi'in. Tidak lupa juga al Fatihah ditujukan kepada Syeh Abdul Kadir Jaelani dan para leluhur. Setelah semua leluhur dikirimi al Fatihah, maka upacara diakhiri dengan do'a. Semua rangkaian menggunakan bahasa Arab, sebagaimana kebiasaan pada acara tahlilan disebagian besar wilayah Indonesia. Doa dipimpin oleh sesepuh yang dianggap yang memiliki ilmu agama lebih dibanding dengan anggota lain, selain tentu saja ketrampilan membaca atau melafalkan bahasa arab secara fasih dan benar.

Pagelaran musik jenengan selalu dimulai dengan sholawat nabi. Allahuma sholi'ala Muhammad. Hal ini dilakukan tidak sekedar penghormatan terhadap nabi, tetapi lebih kepada pemberitahuan anggota kelompok janengan bahwa pertunjukan akan segera dimulai. Seusai sholawat kemudian dalang akan memulai melantunkan lagu diikuti irama musik. Musik janengan tidak mengenal interval instrumen yang kemudian diikuti reference (ref) sebagaimna musik pop, dangdut, atau yang lain. Suara dalang yang terbatas dengan panjang-pendek napas akan dilanjutkan oleh dalang lain, sehingga tidak menimbulkan jeda. Setiap bait tertentu kemudian akan diikuti oleh anggota pemain dan peserta lain yang hadir. Begitu seterusnya saut- menyaut dari awal sampai akhir lagu, seperti yang tersebut saat lagu pembuka:

\section{Lan kulo ngaturi prikso anggen ipun jan janeng samyo \\ Kedah sami anggatekno sambung- sinambung gentos saut sinaut \\ Samyo bantu binantu, sigro lir tindak poncokoro}

Dan saya memberitahu bagaimana cara berjanengan bersama

Harus saling memperhatikan sambung menyambung saut-sautan

Sama-sama membantu, menghindari salah kepahaman

Suara dalang akan menggunakan khas nada tinggi, atau dikenal degan istilah ngelik. Dalam beberapa lagu yang memiliki irama rancak dan enak dinikmati, peserta yang tidak mendapatkan alat musik akan menambahkan irama dengan memukulkan sendok ke piring yang terbuat dari keramik sehingga meninbulkan suara tambahan. Toleransi penambahan suara dari alat lain sangat dimungkinkan untuk menambah suara/ irama yang dihasilkan alat utama. Tidak jarang beberapa peserta lain memberikan tambahan suara dengan cara tepukan tangan lamban teratur mengikuti irama, sebagainana sering dijumpai saat pagelaran wayang kulit.

Sejak keberadaannya enampuluh tahun yang lalu hingga kini pola pertunjukan musik janengan tetap, yaitu para pemain dan anggota lain duduk bersila dalam posisi melingkar atau segi empat mengikuti ruang yang dipakai pertunjukan. Tidak ada pemain yang berdiri dan tidak ada pula tari-tarian yang mengikuti. Pola ini seolah menunjukkan bahwa semua peserta memiliki kedudukan sama, tidak ada keistimewaan antara anggota yang satu dengan yang lain, bahkan termasuk dalang sekalipun. Hak yang memegang alat musiknya dengan yang tidak pun sama. Para peserta yang tidak sedang memainkan alat utama akan dijinkan melakukan penyemangatan dengan ikut bernyayi dan tepuk tangan mengikuti irama yang sedang dilantunkan. 
14 | Mukarom \& Rochsun, Musik Tradisional Jawa Janengan yang Terlupakan ...

Peserta umumnya memakai pakaian ala orang yang akan sholat. Baju takwa (koko) dengan bawahan sarung melilit di tubuh dan kopiah di kepala. Jarang ditemukan peserta yang memakai celana panjang tampa kopiah. Bila ada, umumnya dilakukan mereka yang usianya relatif masih muda. Sama sekali tidak ada yang menunjukkan perbedaan status sosial, ekonomi, atau atribut organisasi tertentu. Mereka hadir betul-betul karena ingin menikmati kesenian. Topik pembicaraan pada sela waktu yang ada tidak ada yang mengarah pada kepentingan hal lain, selain hanya seputar kehidupan sehari-hari: tentang tanaman, pupuk, hewan peliharaan, penyakit, keluarga atau sejenisnya. Proses komunikasi dan topik pembicaraan menujukkan bagaimana keakraban mereka sebagai sebuah komunitas desa yang sederhana yang tetap memperlihatkan budaya kerukunan, keakraban, toleran.

\section{PEMBAHASAN}

Sebagai kesenian yang memiliki sejarah bagi masyarakat, janengan sudah memiliki kontribusi positif terhadap masyarakat, khusunya para transmigran swakarsa. Musik ini mampu menghilangkan sekat perbedaan sub-kultur pada proses akulturasi di daerah transmigrasi swakarsa. Dari segi ketahanan, susah 60 tahun mampu bertahan dan teruji, setidaknya sejak munculnya desa Waringinsari sampai saat penelitian ini dilakukan.

Dalam kurun waktu sekitar 60 tahun lebih keberadaan desa Waringinsari Kabupaten Pringsewu telah mengalami sejumlah perubahan pada hampir semua aspek: sosial, budaya, ekonomi, pertanian, dan bahkan politik. Dalam bidang budaya (seni), telah terjadi pasang surut eksistensi dan keberlanjutan kesenian seiring terjadi perubahan generasi, tingkat kesenangan, dan frekuensi pertunjukan. Hal ini, tentu saja, karena pengaruh media massa yang setiap hari menyajikan hiburan modern. Bahkan, kesenian seperti ketoprak dan janger, sudah berpuluh tahun tidak pernah lagi ada pementasan baik yang bersifat komersial maupun tanggapan warga. Namun, tidak demikian dengan musik janengan. Musik tradisional Islam Jawa ini masih tetap eksis sampai sekarang, bahkan proses perhelatannya juga masih tetap sesuai pakem, tidak mengalami perubahan sejak dahulu sampai sekarang selama rentang waktu sejak keberadaan desa tersebut. Komunitas musik janengan tetap memelihara dan mementaskannya sesuai kebutuhan. Musik janengan tetap eksis menjadi media hiburan, komunikasi, dan dakwah bagi masyarakat desa tersebut. Pada akhir bulan Nopember 2012 saja (memasuki limabelas hari bulan suro- saat penelitian ini ditulis), sudah tiga kali dilakukan pertunjukan janengan. Sehingga selain kegiatan janengan yang dilakukan tidak sekadar memenuhi keinginan rasa seni semata, tetapi juga memiliki nilai luhur pelestarian budaya yaitu peringatan hari besar bulan Jawa (suro). Inilah yang oleh Koentjaraningrat (1990) dikatakan bahwa budaya tidak dengan mudah hilang begitu saja walaupun berpindah tempat tinggal karena mereka akan diwariskan dari satu generasi kepada generasi berikutnya.

Koentjaraningrat (1990:180-182) menyatakan bahwa kebudayaan adalah "keseluruhan sistem gagasan, tindakan dan hasil karya manusia dalam rangka kehidupan masyarakat yang dijadikan milik diri manusia dengan belajar". Kebudayaan juga menyangkut "hal-hal yang bersangkutan dengan akal". Sedangkan terjemahan bahasa Inggris culture (kebudayaan) bermakna "mengolah, mengerjakan" dalam bertani, sehingga arti culture adalah "segala daya upaya serta tindakan menusia untuk mengolah tanah atau merubah alam". Bahkan, kebudayaaan juga mencakup ilmu pengetahuan, kepercayaan, kesenian, moral, hukum, adat istiadat, dan kebiasaan-kebiasaan lain yang terdapat pada masyarakat (Pamungkas, 1990:13). Koetjaraningrat (1990:203-204) melihat bahwa kebudayaan yang bersifat universal mengandung tujuh unsur, antara lain: (1) bahasa, (2) sistem pengetahuan, (3) organisasi sosial, (4) sistem peralatan hidup dan teknologi, (5) sistem matapencaharian hidup, (6) sistem religi, dan (7) kesenian.

Agak sulit rasanya bila masa sekarang mendapatkan kelompok masyarakat yang tidak mengikuti perkembangan yang terjadi, walaupun hanya dalam bidang seni musik. Gencarnya arus komunikasi melalui berbagai media memberikan dampak yang sangat luas terhadap pola hidup dan selera masyarakat, sebab setiap saat masyarakat selalu disuguhi sesuatu yang baru, berbeda, dan menarik dari sisi tampilan dan isi. Itulah sebabnya sulit mempertahankan seni ditengah-tengah budaya yang mengalami perubahan begitu cepat. Melihat kenyataan demikian, menjadi menarik 
kajian mengapa musik janengan menempati tempat tersendiri bagi masyarakat transmigran swakarsa di Waringisari sejak mereka mulai menetap sampai (setidaknya) saat ini.

Tidak hanya gempuran budaya modern yang mengakibatkan sebagaian besar kesenian yang sempat ada di wilayah kajian hilang akibat teknologi informasi. Akan tetapi, perubahan lain juga terjadi pada hampir semua aspek: mata pencaharian, pola pertanian, jenis komoditas, kualitas tanah, budaya (upaca ritual hidup), tansportasi, kekerabatan dan relasi, rumah tinggal, ritual keagamaan, dan lain-lain.

Musik janengan tidak membedakan sekat perbedaan, bersifat egaliter, dan mementingkan kebersamaan. Musik janengan juga memberikan edentitas lokal yang mampu bertahan meski dalam situasi ekomoni serba terbatas. Bahkan dalam gulungan musik modern yang serba kapitalis, musik janengan tetap memiliki segmen tersendiri yang tidak terusik dengan kemerlapnnya musik modern.

Dalam konteks penelitian ini, musik janengan dipandang sebagai media interaksi bagi masyarakat transmigran swakarsa yang memang secara sosiologis merasa membutuhkan interaksi dan pertemanan sejak awal keberadaannya dan hal itu berlangsung hingga saat ini. Teori inteksionisme simbolik Blumer dikembangkan bertumpu pada tiga premis, yaitu: (1) Manusia bertindak terhadap sesuatu berdasarkan maknamakna yang ada pada sesuatu, (2) Makna itu diperoleh dari hasil interaksi sosial yang dilakukan dengan orang lain, (3) Makna-makna tersebut disempurnakan di saat proses interaksi sosial sedang berlangsung (lihat Soeprapto, 2002:120-121; Poloma, 2004:258).

Pentas musik janengan adalah inisiatif para pelaku dan penikmat kesenian. Mereka melakukan pentas musik yang artinya secara langsung ataupun tidak telah melakakukan proses interaksi sosial dengan lingkungan sekitar. Apa yang dilakukan Kaliyo (75) dan Mustamar (Alm.) adalah sebuah inisiatif untuk belajar ke daerah (kabupaten lain) karena mereka merasa memerlukan hiburan, sebuah butuhan adaptif seperti disampaikan Rohidi (2000) dalam penelitiannya. Bagi Blumer, interaksi dalam masyarakat adalah bahwa proses sosial dalam kehidupan kelompoklah yang menciptakan aturan-aturan, bukan aturanaturan yang menciptakan mereka. Kominitas akan membentuk organisasi sebagai alat untuk mereka beraktualisasi, dalam kasus di desa Waringinsari tentu melalui janengan. Kaliyo menceritakan bahwa awal mula adanya musik janengan di desa Waringinsari berawal dari inisiatif dirinya dan Mustamar (alm) tahun 1950an berlajar dan mengikuti latihan musik janengan di daerah Metro (dahulu Lampung Tengah) dan mencatat semua lagu-lagu untuk dibawa dan kemudian ditularkan di desa Waringinsari. Sejalan dengan teori interaksionisme simbolik (Blumer), apa yang dilakukan Kaliyo dan Mustamar (Alm.) mempelajari musik dan kemudian diaplikasinakan bersama komunitasnya tidak lain adalah sebuah "tindakan bersama" (Soeprapto, 2002:132).

Yang membedakan dengan penelitian Rohidi adalah bahwa bila kebutuhan adaptif tetap dilakkan pada orang-orang yang kesulitan secara ekonomi, sementara bagi para transmigran swakarsa tidak hanya masa sulit secara ekonomi tetapi juga disaat mereka teralienasi secara sosial. Jauh dari daerah asal, jauh dari keluarga dan sanak saudara. Perlu diketahui bahwa pada masa awal tinggal di daerah tebangan, belum tentu semua sudahmembawaanakistri.Sebagain masih sendiri dan anak istri baru menyusul beberapa tahun kemudian setelah dirasa situasi memungkinkan. Jadi "tindakan manusia adalah tindakan interpretatif yang dibuat oleh manusia itu sendiri" (Blumer).

Perpektif interaksionisme simbolik Blumer (lihatSoeprapto, 2002:123-124; Poloma, 2004:264266) mengadung ide dasar: (1) Masyarakat terdiri dari manusia yang saling berinteraksi. (2) Interaksi terdiri dari berbagai kegiatan manusia yang berhubungan dengan manusia lain, baik melalui interaksinionisme simbolik maupun interaksionisme non-simbolik. (3) Objek-objek lain tidak memiliki makna yang intrinsik. Makna lebih merupakan produk interaksionisme simbolik. (4) Manusia tidak hanya mengenal obyek eksternal, tetapi mereka juga melihat dirinya sebagai obyek yang lahir di saat proses interaksi simbolis. (5) Tindakan manusia adalah tindakan interpretarif yang dibuat oleh manusia itu sendiri. (6) Tindakan tersebut saling dikaitkan dan disesuaikan oleh anggota kelompok, yang kemudian dianggap sebagai tindakan bersama dan dilakukan berulang-ulang.

Teori interaksionisme simbolik menganggp bahwa manusia melakukan atau bertindak sesuatu berdasarkan "arti". "Arti" dianggap sebagai sebagai sebuah hubungan netral antara 
faktor-faktor yang bertangung jawab terhadap tingkah laku manusia, sedangkan tingkah laku adalah hasil dari beberapa faktor, sehingga interaksionisme simbolik memandang "arti" sebagai produk sosial. Soeprapto mengatakan bahwa prinsip utama teori interaksionisme simbolik adalah apapun yang berorientasi secara empirik atas masyarakat manusia, dari manapun asalnya, harus memperhatikan kenyataan bahwa masyarakat manusia terdiri dari orangorang yang sedang bersama-sama dalam sebuah aksi sosial. Masyarakat merupakan bentuk dari interaksi antar individu. Teori interaksionisme simbolik melihat pentingnya interaksi sosial sebagai sebuah sarana atau penyebab ekspresi tingkah laku manusia. Dalam berbagai hal, seseorang harus masuk kedalam proses pengenalan dari prilakunya agar mengerti tindakannya. Hal ini berlaku untuk aksi bersama atau kolektif dimana sejumlah individu ikut diperhitungkan. Proses sosial dalam kehidupan kelompok akan menciptakan dan menegakkan kehidupan kelompok. Aksi bersama akan mengubah kehidupan kelompok manusia dan akan menyajikan pertalian horisontal dan vertikal (Soeprapto, 2002:139-146).

Senada dengan apa yang disampaikan Blumer, Agus (2010:156) menyatakan bahwa manusia memiliki dimensi fisik, akal, rasa,dan hati. Keempatnya merupakan kebutuhan dasar manusia yang apabila salah satu atan beberapa diantaranya terabaikan akan menimbulkan kekurangan, ketimpangan, dan bahkan penyakit. Aspek fisik dan makanan akan melahirkan manusia yang sakit-sakitan, tanpa pengembangan ilmu pengetahuan akan melahirkan manusia bodoh dan terbelakang, tanpa rasa dan seni hidup menjadi gersang dan hambar, tanpa hati nurani hidup kehilangan makna. Dengan ilmu hidup akan menjadi terang dan dengan seni hidup akan menjadi lebih indah.

\section{KESIMPULAN DAN SARAN}

Bertitik tolak dari masalah dan tujuan penelitian, maka kesimpulan yang dapat ditarik adalah: (1) Bahwa musik janengan masih sangat digemari dan dibutuhkan di desa Waringinsari. Itulah sebabnya hingga kini pentas masih dilakukan baik untuk kepentingan hiburan maupun terkait dengan hari besar agama dan penanggalan Jawa, sehingga masih dapat dipakai sebagai pelestarian budaya. (2) Musik janengan juga dijadikan media berkomunikasi dengan sesama komunitas untuk kepentingan sosial kemasyarakatan sehinga mereka dapat berbagi informasi terkait dengan keluarga, pertanian, peternakan, dan lain-lain. (3) Musik janengan juga dapat digunakan komunits untuk saling meneguhkan segai identitas keislaman dengan selalu mengikuti sunah rosul dan tidak berbiat kesombongan atas segala sesuatu yang dimiliki.

Sudah seharusnya peran pemerintah bisa dilakukanuntukmelestarikan budaya seni musik tradisional Islam. Upaya bisa dilakukan dalam bentuk lomba musik janengan secara teratur, dapat juga dengan mengundang mereka secara resmi pada acara tertentu yang diselenggarakan pemerintah. Lebih dari itu perlu upaya yang dapat memfasilitasi untuk merekam dan menjual secara komersial sehingga selain ada unsur pelestrian budaya, juga bisa mendapatkan nilai tambah secara ekonomi. Lebih-lebih bila peran pemerintah bisa mematenkan agar suatu saat tidak diklaim pihak lain.

\section{DAFTAR RUJUKAN}

Agus, B. 2010. Agama dan Fenomena Sosial: Buku Ajar Sosiologi Agama. Jakarta: UI Press.

Alisadono,S.,dkk. 2006."Kebijakan Transmigrasi Melalui Pendekatan Sistem". Ilmu Tanah, Tim Fakultas Pertanian Universiatas Gadjah Mada

Arsyad, L., et.al. 2011. Stategi Pembangunan Pedesaan Berbasis Lokal. Yogyakarta: UPP STIM YKPN

Basrowi dan Sudikin. 2002. Metode Penelitian Kualitatif, Perspektif Mikro. Surabaya: Insan Cendikia.

Creswell, J. W. 2010. Research Design: Pendekatan Kualitatif, Kuantitatif, dan Mixed. Edisi ketiga. Yogyakarta: Pustaka Pelajar.

Denzin, N. K. Dan Lincoln (Editors). 1997. Handbook of Qualitative Reseach. New Delhi: Sage Publication. Pvt. Ltd.

Emzir. 2011. Metodologi Penelitian Kualitatif: Analisis Data. Jakarta: Rajawali Pers.

Faisal, S. S. 1998. Budaya Kerja Masyarakat Petani: Kanjian Strukturasionistik Berdasarkan Kasus Petani Sumbawa. Disertasi. Surabaya: Program Pascasarjana Universitas Airlangga. 
Hadi, Y. S. 2006. Seni dalam Ritual Agama. Cet. II. Yogyakarta: Pustaka.

Haryanto, Sindung. 2012. Spektrum Teori Sosial: Dari Klasik Hingga Pos-Modern. Yogyakarta: Ar-Ruzz Media

Koentjaraningrat. 1990. Pengantar Ilmu Antropologi. Cetakan kedelapan. Jakarta: PT Rineka Cipta.

Levang, P. dan Sevin, O. 1990. 2nd Ed. “80 Years of Transmigration in Indonesia 1905-1985". Jakarta: Departemen Transmiggrasi Biro Perencanaan dan OSTROM c/o Embassy.

Moloeng, L.J.2011. Metodologi Penelitian Kualitatif. Edisi Revisi, Cet. 29. Bandung: PT. Remaja Rosdakarya.

Muarief, S. 2002. Mengenal Budaya Masyarakat Using. Penerbit SIC.

Poloma, Margaret M. 2004. Sosiologi Kontemporer. Jakarta: RajaGtafindo Persada.

Rahardjo, M. 2007. Sosiologi Pedesaan: Studi Perubahan Sosial. Malang: UIN-Malang Press.

Rahyono, F.X. 2009. Kearifan Budaya dalam Kata. Jakarta: Wedatamawidyasastra.
Rohidi, T. R. 2000. Ekspresi Seni Orang Miskin. Nandung: Penerbit Nuansa.

Spradly, J. P. 1997. Metode Etnografi. Yogyakarta: Tiara Wacana.

Soeprapto, H.R. R. 2002. Interaksionisme Simbolik: Perspektif Sosiologi Modern. Malang: Averroes Press dan Pustaka Pelajar.

Sumardjo, J. 2000. Filsafat Seni. Bandung: Penerbit ITB.

Suyabrata, S. 2002. Metodologi Penelitian. Jakarta: RajaGtafindo Persada.

Storey, J. 2003. Teori Budaya dan Budaya Pop. Terjmh. Yogyakarta: Penerbit Qalam

Sugiono. 2010. Metode Penelitian Kuantitatif Kualitatif. Bandung: Alfabeta.

Triwurjani, Rr. 2011. Situs-situs Megalitik di DAS Sekampung. Jakarta: Penerbit Wedatama Widya Sastra.

Yurisaldi. Tanpa tahun. Rahasia Kebudayaan Jawa: Tinjauan Kedokteran Modern. Yogyakarta: Aule Book.

Weintraub, A. N. 2012. Dangdut. Jakarta: KPG (Kepustakaan Populer Gramedia) 
18 | Mukarom \& Rochsun, Musik Tradisional Jawa Janengan yang Terlupakan ... 